\title{
ASSESSMENT OF WOMEN"S RESPONSES TOWARD COMMON GYNECOLOGICAL SYMPTOMS IN PORT-SAID CITY
}

\section{Prof. Sanaa Aly Nor; Dr. Manar Fathy Heeba; Samar Mouhamed Moukhtar.}

Prof of Obstetric and Gynecology, Faculty of Nursing, Zgazig University; Lecturer of Maternity, Obstetric and Gynecological Nursing, Faculty of Nursing, Port said University; BSC Nursing, Faculty of Nursing, Suez Canal University

\begin{abstract}
Aim: The aim of this study was to assess women's responses toward common gynecological symptoms.

Subject and Methods: The study was carried out at gynecological clinics in 5 health centers selected randomly from twelve centers in Port-Said using a cross-sectional descriptive design. The study subjects consisted of 500 users of gynecological care services. An interview schedule was designed and utilized to collect the necessary data.

Results: The results of this study revealed that $75.4 \%$ of women suffered from leucorrhea, $63.8 \%$ complained of dysmenorrhea, $58.6 \%$ had pruritus vulva and $39.8 \%$ of the studied subjects had menorrhagia. A significant relation was found between the seeking treatment behavior and related independent variables among the studied women.

Recommendations: the study recommended the development and dissemination of training courses and education programs for the decision makers, workers in health care settings and gynecological clinics to raise awareness of the seriousness of gynecological symptoms facing women and how to address it.
\end{abstract}

Conclusion: It was concluded that gynecological symptoms has negative effects on women's quality of life and some women's responses may be harmful.

Key words: Gynecological symptoms, Responses. 


\section{INTRODUCTION}

Reproductive health, a crucial aspect of general health is of significant importance for human development especially for women particularly during the reproductive years. Although most reproductive health problems arise during the reproductive years, in old age general health continues to reflect earlier reproductive life events. Failure to deal with reproductive health problems in terms of obstetric or gynecological disorders at any stage in life sets the scene for later health and developmental problems (Tehrani et al., 2011).

Gynecological health is an important component of any woman's health status. Gynecological disorders can have a substantial impact on many aspects of quality of life, including reproductive ability, sexual functioning, mental health, and the ability to work and to perform routine physical activities (Inamdar et al., 2013).

Gynecological disorders cover a range of conditions with a wide spectrum of lethality and chronicity and a substantial impact on women's quality of life. Racial and geographic variations in disease and social conditions mean that biomedical as well as social science perspectives should come together in providing consistent information for policymakers on this important aspect of women's health (William \& Zö̈, 2012).

According to WHO, reproductive ill health accounts for 36.6 per cent of the total disease burden among women aged 15 to 45 years at global level. In Egypt, though there are not many studies on women's reproductive morbidity in terms of gynecological diseases, the available data indicate high prevalence in comparison to other developing and its neighboring countries. Almost 39 percent of currently married women in Egypt report at least one reproductive health problem related to vaginal discharge, urination or intercourse (WHO, 2005).

Addressing gynecological symptoms is a complex process as women either don't consider it a significant health problem or hesitate to talk on it and other determinants like illiteracy, ignorance, gender discrimination \& poor social status, lack of decision making power especially in women from socially \& economically backward areas, further complicates the problem \& reduces reporting of cases and delayed treatment which ultimately increases the prevalence (Gaash et al., 2005).

Women's responses to common gynecologic symptoms vary widely. Many national studies stated that most women might internalize their reproductive problems as part of a "culture of silence". Women tend to internalize ailments such as "pain and discomforts emanating from their reproductive and sexual roles are accepted as the very essence of womanhood". These 
women perceive their condition as either being unworthy of medical attention, too costly to address or as part of their burden in life (Kaur et al., 2013).

Nursing intervention is an integral component of nursing practice and a major concern for most nurses. The nurse can give information; encourage the positive attitudes towards common gynecological symptoms. In addition, she can provide care for women with these problems (Guyton \& Hall, 2006).

\section{AIM OF STUDY:}

The aim of this study is to assess women's responses toward common gynecological symptoms in Port Said city.

\section{SUBJECT AND METHODS:}

A cross sectional descriptive design was utilized in this study to assess women's responses toward common gynecological symptoms. The present study was carried out in gynecological clinics in 5 health centers in Port-said selected randomly from twelve centers; namely: El Manakh, Bank-Elescan, El-Arab, El-Gawhara, and El-Kuwait centers. The subjects consisted of $\mathbf{5 0 0}$ women, they were selected from the aforementioned setting according to the following criteria: Women at reproductive age ranged between 19 to 45 years \& women who complained of four selected gynecological symptoms. A consecutive sample of women fulfilling the foregoing criteria was recruited from the study setting until the required sample size (500) was obtained. Structured interview form was utilized by the researcher to collect necessary data.

\section{The questionnaire consisted of two parts as the following:}

\section{The First Part:}

- This part included socio demographic characteristic such as age, education, occupation, marital status, size of the family, and family income.

- Menstrual history such as age of menarche, rhythm, interval, duration, and amount of menstruation as well as number of pads/ day.

\section{The Second Part:}

- Current gynecologic symptoms such as type, duration and character of these symptoms.

- Women's responses toward these symptoms such as after how long they responded, nature of response (doing nothing, seeking or embarrassing to seek medical advice or performing traditional practices) in addition to the resource persons for their response. 


\section{Content Validity:}

After the tool had been designed, it was tested for its validity and reliability. Then the pilot study was carried out on $10 \%$ of the sample in the study setting that were excluded from the study sample. The purposes of the pilot study were to test the applicability and clarify the feasibility of the study tools and it served to estimate the time needed to complete the tools. It also helped to find out any obstacles and problems that might interfere with data collection, based on findings of the pilot study, certain modification of the tools were done. Subjects included in the pilot study were excluded from the study subjects. Following this pilot study, the process of data collection was performed.

\section{RESULTS}

Table 1 illustrates the distribution of the studied sample according to their sociodemographic characteristics. As regards age, it was observed that the age of nearly half (48.8\%) of women ranged between $25-35$ years, while the age of less than one third $(30.8 \%)$ of them ranged between 35-45 years, with a mean age of women was 30.4 \pm 6.5 . Concerning the level of education, more than half $(55.8 \%)$ of women had secondary level of education, while only $9.8 \%$ were illiterate. The majority $(70.0 \%)$ of women was housewives, and their income just meets their expenses $(65.8 \%)$.

Figure 1 shows distribution of women according to the prevalence of common gynecological symptoms. Leucorrhea presented among almost three-quarters of the studied women (75.4\%). Meanwhile, less than two thirds (63.8\%), of women were suffered from dysmenorrhea and more than half $(58.6 \%)$ complained of pruritus vulvae. As for menorrhagia it presented in $39.8 \%$.

Table 2 illustrates distribution of women according to the received medical advice for dysmenorrhea. More than two thirds $(63.3 \%)$ of women did not seek medical advice because they believed that it is a normal symptom (90.1\%). The table also shows the vast majority (95.6\%) of the studied women drinking warm fluids such as mint, helba and anise, taking analgesics (61.8\%) without doctororder"voltarin, brufen and ketofan", laying on the abdomen (41.7\%), using hot foments on abdomen (38.6\%). Few women used abdominal wrap (2.2\%), or sat in warm water (1.6\%). As for their source of knowledge, the main source of instructions was the mother and mother in low (56.7\%), physician/ nurse (37.6\%), pharmacist $(21.3 \%)$ or the relatives $(24.5 \%)$. 
Table 3 presents distribution of women according to the received medical advice for menorrhagia. The majority of women $(85.9 \%)$ sought medical advice, while $14.1 \%$ of them didn't seek it because of financial causes (39.3\%), increased responsibilities $(32.1 \%)$, or due to negligence $(28.6 \%)$.

The table also shows that almost three quarters (74.9\%) of the women prefered to rest in bed and 64.3\% received anti-coagulants "dycienon without doctor prescription". Iron tablets, contraceptive pills, traditional methods also used by a sizable proportion $(52.3 \%, 28.1 \%$, and $27.1 \%$ respectively). As for their source of knowledge, the main source of knowledge was the physician/nurse ( $81.4 \%)$, followed by the pharmacist (6.0\%) and family members $(6.0 \%)$.

Table 4 illustrates distribution of women according to the received medical advice for leucorrhea. More than one-half of women (55.2\%) sought medical advice, while $44.8 \%$ didn't seek it mainly because they believed that leucorrhea is a normal symptom (81.7\%). The same table reveals that applying vaginal ointment or suppository such as amirzol was used by almost half of the sample $(51.2 \%)$ and $47.2 \%$ reported that they sat in warm water with disinfectant. However, more than one third used vaginal douches, or washes the perineal area with soap and water (13.8\% and $22.0 \%$ respectively). As for the women source of information, it mostly done by the physician/nurse (51.7\%), followed by an equal percentage of family members and relatives $(14.8 \%$ and $14.8 \%$ respectively).

Table 5 indicates that the majority (79.2\%) of women sought medical advice, while $20.8 \%$ of them didn't seek it because of financial causes $(44.3 \%)$, increased responsibilities $(36.1 \%)$ or considered it as a normal symptom $(6.5 \%)$. The table also shows that the majority of women $(82.9 \%)$ applied oil or soothing cream (betaderm) to the vulva. As for their source of knowledge, it was found that doctor/nurse was the source of information for more than three quarters of women (76.8\%). However, a high percentage obtained their information from relatives and friends or the pharmacist ( $28.6 \%$ and $33.4 \%$ respectively). 
Table (1): Distribution of women according to their socio-demographic characteristics

\begin{tabular}{||l|c|c||}
\hline \multirow{2}{*}{ Socio-demographic characteristics } & \multicolumn{2}{c|}{$\begin{array}{c}\text { Studied Women } \\
(\mathbf{n = 5 0 0})\end{array}$} \\
\cline { 2 - 3 } & No. & $\%$ \\
\hline Age (years) & 102 & 20.4 \\
19- & 244 & 48.8 \\
25- & 154 & 30.8 \\
35+ & & \\
Educational level of mother & 49 & 9.8 \\
Illiterate & 65 & 13.0 \\
Primary/ Preparatory school & 279 & 55.8 \\
Secondary/technical school & 107 & 21.4 \\
University & 350 & 70.0 \\
\hline Occupation: & 150 & 30.0 \\
Housewife & & \\
Working & 419 & 83.8 \\
\hline Family size & 81 & 16.2 \\
2-5 members & 154 & 30.8 \\
6 or more & & 65.8 \\
\hline Monthly income & 329 \\
In debt & 17 & \\
Just meeting expenses & & \\
Able to save & & \\
\hline \hline
\end{tabular}

Figure (1): Prevalence of different types of common gynecological symptoms

\begin{tabular}{|r|r|r|}
\hline 80 \\
70 \\
60 \\
50 \\
40 \\
30 \\
\hline 20 \\
10 \\
0
\end{tabular}


Table (2): Distribution of women according to their responses toward dysmenorrhea

\begin{tabular}{|c|c|c|}
\hline \multirow{2}{*}{ Seeking treatment for dysmenorrhea } & \multicolumn{2}{|c|}{$\mathbf{n}=\mathbf{3 1 9}$} \\
\hline & No. & $\%$ \\
\hline $\begin{array}{l}\text { Seek medical advice [n=319] } \\
\text { No } \\
\text { Yes }\end{array}$ & $\begin{array}{l}202 \\
117\end{array}$ & 36.7 \\
\hline $\begin{array}{l}\text { Causes of refusing medical advice [n=202] } \\
\text { Financial causes } \\
\text { Lack of time } \\
\text { Normal symptom }\end{array}$ & $\begin{array}{c}15 \\
5 \\
182\end{array}$ & $\begin{array}{r}7.4 \\
2.5 \\
90.1\end{array}$ \\
\hline $\begin{array}{l}\text { Methods used [n=319] } \\
\text { Nothing } \\
\text { Take analgesics } \\
\text { Hot drinks } \\
\text { Lay on abdomen } \\
\text { Use hot foments on abdomen } \\
\text { Wrap abdomen } \\
\text { Sit in warm water }\end{array}$ & $\begin{array}{c}7 \\
197 \\
305 \\
133\end{array}$ & $\begin{array}{l}2.2 \\
61.8 \\
95.6 \\
41.7\end{array}$ \\
\hline $\begin{array}{l}\text { \#Source of knowledge [n=319] } \\
\text { No one } \\
\text { Mother/mother in low } \\
\text { Neighbors/friends } \\
\text { Relatives } \\
\text { Physician/nurse } \\
\text { Pharmacist }\end{array}$ & $\begin{array}{c}50 \\
181 \\
21 \\
78 \\
120 \\
11\end{array}$ & $\begin{array}{r}15.7 \\
56.7 \\
6.6 \\
24.5 \\
37.6 \\
3.4\end{array}$ \\
\hline
\end{tabular}


Table (3): Distribution of women according their responses toward menorrhagia .

\begin{tabular}{|l|c|c||}
\hline \multirow{2}{*}{ Received medical advice for menorrhagia } & \multicolumn{2}{|c|}{ n=199 } \\
\cline { 2 - 3 } Seek medical advice [n=199] & No. & \% \\
No & 28 & 14.1 \\
Yes & 171 & 85.9 \\
\hline Causes of refusing medical advice [n=28] & 11 & \\
Financial causes & 9 & 39.3 \\
Increase responsibilities & 8 & 28.6 \\
Negligence & & \\
Methods used [n=199] & 104 & 52.3 \\
Receive iron tablets & 128 & 64.3 \\
Receive anti-coagulatns & 56 & 28.1 \\
Receive contraceptive pills & 149 & 74.9 \\
Rest in bed & 44 & 22.1 \\
Frequent female hygiene & 3 & 1.5 \\
Eat special food & 7 & 3.5 \\
Traditional remedies & 6 & 61.4 \\
\hline \#Source of knowledge [n=199] & 3 & 1.5 \\
No one & 62 & 3 \\
Mother/mother in low & 6 \\
Neighbors/friends/relatives & & 3 \\
Pharmacist & & 6 \\
Physician/nurse & & \\
\hline & & \\
\hline
\end{tabular}


Table (4): Distribution of women according to their responses toward leucorrhea

\begin{tabular}{|c|c|c|}
\hline \multirow{2}{*}{ The received medical advice for leucorrhea } & \multicolumn{2}{|c|}{$\overline{n=377}$} \\
\hline & No. & $\%$ \\
\hline \multicolumn{3}{|l|}{ Seek medical advice[n=377] } \\
\hline No & 169 & 44.8 \\
\hline Yes & 208 & 55.2 \\
\hline \multicolumn{3}{|l|}{ Causes of refusing medical advice [ $n=169]$} \\
\hline Financial causes & 14 & 8.3 \\
\hline Lack of time & 17 & 10.0 \\
\hline Considered as normal & 138 & 81.7 \\
\hline \multicolumn{3}{|l|}{ Methods used[n=377] } \\
\hline Nothing & 10 & 2.6 \\
\hline Vaginal douches & 52 & 13.8 \\
\hline Wash with soap and water & 83 & 22.0 \\
\hline Sit in warm water with disinfectant & 178 & 47.2 \\
\hline Wash after each urination and defecation from front to back & 5 & 1.3 \\
\hline Use frequent sanitary pads & 20 & 5.3 \\
\hline Use ointment or vaginal suppositories & 193 & 51.2 \\
\hline Sit in warm water with vinegar & 2 & 0.5 \\
\hline \multicolumn{3}{|l|}{ \#Source of knowledge [n=377] } \\
\hline No one & 34 & 9.0 \\
\hline Mother/mother in low & 56 & 14.8 \\
\hline Neighbors/friends & 22 & 5.8 \\
\hline Relatives & 56 & 14.8 \\
\hline Physician/nurse & 195 & 51.7 \\
\hline Pharmacist & 19 & 5.0 \\
\hline Media & 10 & 2.6 \\
\hline
\end{tabular}


Table (5) Distribution of women according to their responses toward pruritus vulvae.

\begin{tabular}{|c|c|c|}
\hline \multirow{2}{*}{ Items } & \multicolumn{2}{|c|}{$\mathrm{n}=\mathbf{2 9 3}$} \\
\hline & No. & $\%$ \\
\hline \multicolumn{3}{|l|}{ Received medical advice for pruritus vulvae: } \\
\hline \multicolumn{3}{|l|}{ Seek medical advice $[\mathrm{n}=293]$} \\
\hline No & 61 & 20.8 \\
\hline Yes & 232 & 79.2 \\
\hline \multicolumn{3}{|c|}{ Causes of refusing seeking medical advice $[n=61]$} \\
\hline Financial causes & 27 & 44.3 \\
\hline Increase responsibilities & 22 & 36.1 \\
\hline Husband disapproval & 8 & 13.1 \\
\hline Considered as normal & 4 & 6.5 \\
\hline \multirow{2}{*}{\multicolumn{3}{|c|}{$\begin{array}{l}\text { Methods of coping with pruritus vulvae: } \\
\text { Methods used [n=293] }\end{array}$}} \\
\hline & & \\
\hline Wear cotton underwear & 207 & 70.6 \\
\hline Wash genitalia with warm water & 120 & 40.9 \\
\hline Wash genitalia with warm water and soap & 42 & 14.3 \\
\hline Use oil or cream on genitalia & 243 & 82.9 \\
\hline \multicolumn{3}{|l|}{ \#Source of knowledge [ $n=293$ ] } \\
\hline No one & 39 & 13.3 \\
\hline Mother/mother in low & 45 & 15.3 \\
\hline Neighbors/friends & 6 & 2 \\
\hline Relatives & 33 & 11.3 \\
\hline Physician/nurse & 225 & 76.8 \\
\hline Pharmacist & 98 & 33.4 \\
\hline Media & 5 & 1.7 \\
\hline
\end{tabular}




\section{DISCUSSION}

Gynecological health is an important component of any woman's health status. Gynecological disorders can have a substantial impact on many aspects of quality of life, including reproductive ability, sexual functioning, mental health, and the ability to work and to perform routine physical activities. Information about reproductive morbidity in developing countries is scanty and mainly based on information obtained from clinics or hospitals. However, large proportion of women doesn't visit such facilities; results are not usually reflecting the true magnitude of the disease burden. This type of information is better obtained through community-based self-reporting surveys (Inamdar et al., 2013).

As for the prevalence of dysmenorrhea, the present study found that, more than three-fifths of menstruating women were exposed to dysmenorrhea. The high prevalence of dysmenorrhea in the present study is ascribed to the lack of women's knowledge about dysmenorrhea and the simplest techniques of coping with it. Similarly Burnett et al. (2005); Singh et al. (2008) reported that, the prevalence rate of dysmenorrhea ranges between $28.0 \%$ and $71.7 \%$ and that primary dysmenorrhea affected approximately $73.8 \%$ out of total of 107 female medical students at Indian Medical College, department of physiology. Also, a study of 408 young Italian women by Grandi et al. (2012) found that the prevalence of dysmenorrhea was $84.1 \%$.

Concerning seeking medical advice for dysmenorrheal, the current study finding showed that more than one third of women sought medical advice, while more than three fifth did not ask for help. In the same line, Mohamed (2012) found that $73.0 \%$ used to treat themselves without medical prescription since they were acquainted with the medications to alleviate their symptoms of dysmenorrhea. Meanwhile, most of them responded to dysmenorrhea by drinking warm fluids such as mint, helba and anise. While, more than three fifths took analgesics without doctor prescription such as; voltaren, brufen and ketofan and more than two fifths responded by lying on their abdomen. In line with this Mohamed (2012), study in Assiut City, Egypt found that analgesics was used by more than one half $(56.0 \%)$ of the studied subjects, followed by, rest (49.0\%), drinking hot tea $(26.1 \%)$, herbal drinks $(20.1 \%)$, applying heating pad on the abdomen $(14.9 \%)$, or exercises $(7.0 \%)$. 
The present study has also revealed that almost two fifth of the studied subjects suffered from menorrhagia. In disagreement with this Warrilow et al. (2004) study in North Staffordshire Hospital/Keele University showed that one in 20 women aged between 30 and 49 years consults her general practitioner each year with heavy menstrual loss. In this respect, the world health orgnization indicated that 18 million women aged 30-55 years perceive their menstrual bleeding to be exorbitant and 10.0\%-20.0\% of all menstruating women experience blood loss severe enough to be defined clinically as menorrhagia (Shaw, 2004).

Regarding the medical advice for menorrhagia it was sought by majority of women in the present study. Deeb et al. (2003) study in Lebanon reported similar results and found that menstrual irregularity and bleeding problems were considered the two of the top three reasons reported for seeking gynecological care. In contrast, Khattab et al. (2000) found that women avoid consulting doctors because of physical inaccessibility, inadequate quality and nature of available services as well as lack of communication with and fear of being treated poorly by provider. This is disagreeing with the present study finding, where women didn't seek medical advice because of financial reasons, increased responsibilities and negligence. The differences in outcomes among the aforementioned studies and the present one may be due to variations in study design and the impact of confounding factors influencing menorrhagia.

Regarding women's responses to menorrhagia, almost three quarters of women preferred to rest in bed during menstruation, they thought that decreasing the physical activity will decrease the amount of blood loss. Meanwhile, more than three-fifths took anticoagulant. This finding is similar to Protheroe (2004) who observed that women with heavy menstrual bleeding have also been found to have increased level of enzymes that cause fibrinolysis. Therefore, coagulant drugs have been promoted for the treatment of menorrhagia. These drugs have been found to reduce menstrual blood loss by up to $50 \%$. Furthermore, more than half of women in the present study responded to their menorrhagia by taking iron supplement. In fact, the relationship between iron deficiency and menorrhagia is complicated. Not only can menorrhagia lead to iron deficiency, but iron deficiency can also lead to or aggravate menorrhagia by reducing the capacity of the uterus to stop bleeding. Supplementing with iron decreases excess menstrual blood loss in iron deficient women who have no other underlying cause for their condition (Health Notes, 2006). 
Worldwide, excessive vaginal discharge or leucorrhea is one of the most common and chief complaints in clinical medicine. It accounts for more than 10 million office visits annually (National Center for Health Statistics, 2009). The present study has also demonstrated that the majority of women experienced abnormal vaginal discharge. This finding is serious since excessive vaginal discharge is one of the strongly accepted criteria suggesting RTI (El Shenawy, 2005). Such finding is partially in agreement with Omokanye et al. (2014) who found that the majority $(90.7 \%)$ of the studied women had suffered from morbidity related to their reproductive tract in the last 3 months and the frequently experienced symptom was leucorrhea $(63.8 \%)$.

Regarding the perceived nature of leucorrhea, the results of present study revealed that some women perceived it as a normal event in their reproductive age. In partial agreement with the foregoing present study finding Manjula \& Rumana, (2006) in Nagpara showed that women's perception of leucorrhea is embedded in the reproductive process and unfavorable gender norms related to their everyday realities of life. While $60.0 \%$ of women recognized marriage and heavy workload as the root cause of white discharge, others attributed white discharge to external factors like hot weather. Over 50.0\% women corelated physical symptoms of white discharge with their overall family and village situation.

Inquiry about seeking medical advice by women with leucorrhea revealed that more than two-fifth of them never consulted a physician. In addition, it was found that sizeable proportion of women sought medical advice after a long time of the onset of leucorrhea. This was mainly due to negligence, lack of money, increased responsibilities as well as their belief that this symptom is normal. These findings are in agreement with Khattab et al. (2000) in rural Egypt who claimed that women tend to seek medical help only if an illness is advanced, and reasons beyond women's delay in seeking medical care for vaginal discharge are personal, social and professional.

Personal reasons include lack of time because of work and family demands, lack of money, as well as need for permission or to be accompanied by family member to health care facility. Social reasons include; culture of silence and endurance, stigma attached to leucorrhea which may indicate RTIs, reluctance to be examined by male doctor as well as poor perception of quality of care at governmental level. Professional reasons include lack of 
female physician and attitude of health workers. These reasons are considered as constraints on women's access to health care.

On analyzing women's responses regarding vaginal discharge in the present study, it was observed that majority of women performed harmful practices such as washing the vulva with soap and water, sitting in warm water with antiseptic solution as well as making vaginal douche. This finding may be explained by the fact that most women consider their mothers, mother in low, other family members or friends as the first line of help and consultation whenever they feel they have a problem.

It is well known that such harmful responses e.g., washing the vagina with soap and water leads to irritation and burning sensation (Klebanoff et al., 2010). Moreover, sitz bath allows microorganisms to spread from the anal area to the vagina and urethra, so it leads to genital and urinary tract infections (Guyton \& Hall, 2006). In addition, the inability of women to calculate the right dose or being unaware of the exact route of drug administration leads to irritation, ulceration or the uselessness of the drug (Klebanoff et al., 2010). Aside from the harmful responses, helpful responses were not hidden from the view of the present study. They were found in the form of applying vaginal ointment or suppository and performing frequent perineal care from front to back. This finding is in harmony with El-Shinawy (2005) and who mentioned that these practices help prevent vaginal infection and excessive vaginal discharge.

Lastly, the current study results indicated that the prevalence of pruritus vulva was more than two thirds of women thus it was the second common gynecological symptom in this study. This finding is similar to Panda et al. (2013) study in in north coastal Andhra Pradesh, India who found that pruritus valvae was the second common clinical presentation $(60.0 \%)$. Moreover, the present study results revealed that almost one fifth of the studied women didn't seek medical advice mainly because of financial causes and increased responsibility. This finding is partially similar to Cornally \& McCarthy (2011) who claimed that there are psychosocial factors including past help seeking, outcome expectancy, agerelated beliefs, social cost and social influence have great impact on individual seeking behavior.

The present study results revealed that the majority of women used cotton underwear. This correspond well with EMIS \& Patient Information Publications (2004) who advised women 
to use lose fitting cotton underwear and to avoid tight jeans, to allow some air to get to the vulva, and overcome sweetness. Cotton underwear is recommended for good personal hygiene because it is less allergic, absorbs vaginal secretion and prevents irritation. It could also be boiled and properly cleaned. Another sizeable proportion of women in the present study responded to pruritus vulvae by washing the perineum with warm water, water and soap or applying oil or cream to the vulva. All these are considered harmful practices because sometimes soaps can irritate the delicate vulval skin, and using large amount of washing powder and scented soaps may increase irritation and consequently may lead to chemical ulceration. The most important is treating the cause of pruritus valvae (EMIS, 2004). That is why the majority of the studied women sought medical advice and did not consult family members for this problem. This finding is not in line with the study of El-Shinawy (2005), in which women claimed that mother, sister or mother in law were persons to be notified because they are more experienced and will give them honest and confidential advice.

\section{CONCLUSION:}

\section{Based on study findings, it can be concluded that:}

Almost three-quarters of the studied women had leucorrhea, more than three-fifths of the studied sample had dysmenorrhea, more than half complained of pruritus vulva and almost two-fifths of them had menorrhagia. Gynecological symptoms had negative effects on women's quality of life and some women's responses may be harmful. In addition, there was a significant relation between seeking treatment and related independent variables.

\section{RECOMMENDATIONS:}

Based on the results of the present study, the following recommendations were suggested:

Maternity nurses at Port Said should acquire the knowledge of common gynecological symptoms to assist with patient assessment and counseling. Meanwhile, simple illustrative printed materials about common gynecologic symptoms and how can women deal with it should be designed by specialized personnel and be made available to all women in gynecological clinics.

\section{REFERENCES}

Burnett MA., Antao V., Black A., Feldman K., Grenville A. and Lea R. (2005): Prevalence of dysmenorrhea in Canada. J Obstet Gynaecol Can; 27(8): 765-70. 
Cornally N. and McCarthy G. (2011): Help-seeking behaviour for the treatment of chronic pain. Br J Community Nurs 2011, 16:90-98. PubMed Abstract

Deeb ME., Yeretzian JS. and Kaspar HG. (2003): Prevalence of reproductive tract infections, genital prolapse, and obesity in a rural community in Lebanon. Bulletin of the World Health Organization, 81:639-645. PubMed Abstract.

El-Shenawy S. (2005): Effect of counseling approaches on the utilization of health services by women with reproductive tract infections. Doctorate Thesis. Faculty of Nursing, University of Alexandria.

Eman M. Mohamed (2012): Life Science Journal, Epidemiology of Dysmenorrhea among Adolescent Students in Assiut City, Egypt; 9(1).

EMIS andPatient Information Publications (2004): Pruritus vulva. Available at.URL: Http:// dermentz.org/site-age-specific/pruritus-vulvae-girlshtml. Last accessed on: 22 November 2006.

Fahimeh Ramezani Tehrani, Masoumeh Simbar, and Mehrandokht Abedini (2011): Reproductive morbidity among Iranian women; issues often inappropriately addressed in health seeking behaviors. BMC Public Health 2011, 11:863

Gaash B., Kausar R. and Bashir S. (2005): Reproductive Tract Infections in Kargil: A community based study. Healthand Population-perspectives and issues; 28 (1): 1-8.

Grandi G., Ferrari S., Xholli A., Cannoletta M., Palma F. and Romani C.(2012): Prevalence of menstrual pain in young women: what is dysmenorrhea? J Pain Res.;5:169-74.

Guyton AC. and Hall JE. (2006): Textbook of Medical Physiology $11^{\text {th }}$ ed. Elsevier Saunders, Philadelphia.

Harlow SD. and Campbell OMR. (2000):"Menstrual dysfunction: a missed opportunity for improving reproductive health in developing countries," Reproductive Health Matters, vol. 8, no. 15 , pp. 142-147.

Health Notes Menorrhagia (2006): Available at URL:

http://www.Pccnaturalmarkets.com/health/concern/menorrhagia.htm. Last accessed on: 23

November 2007. 
Inamdar IF., Sahu Priyanka C. and Doibale MK. (2013): IOSR Journal of Dental and Medical Sciences (IOSR-JDMS),E-ISSN: 2279-0853, p-ISSN: 2279-0861. Volume 7, Issue 6 (Mar-Apr.), PP 05-11 www.iosrjournals.org; www.iosrjournals.org.

Khattab H., Younis N. and Zurayk H. (2000): Rural Egyptian women bear heavy disease burden. Population Briefs; 6(2).

Klebanoff MA., Nansel TR. and Brotman RM. (2010): Personal hygienic behaviors and bacterial vaginosis. Sex Transm Dis 37(2):94.

Manjula Singh and Rumana Jesmin Khan (2006): BRAC University Journal, Vol. III, No. 1, pp. 17-26.

National Centre for Health Statistics (2009): National Ambulatory Medicine Care Survey. Available at www.cdc.com/nchs/about/major/ahcd/ahcd1.htm.

Omokanye LO., Salaudeen AG. and Yusuf AS (2014): Reproductive health problems and health seeking behavior of female sex workers in Sabon Gari Local Government Area, Zaria, Nigeria. Volume: 17 Issue: 1 P 23-28.

Potter P. and Perry A. (2001): Fundamentals of nursing $5^{\text {th }}$ ed. Philadelphia: Mosby; 1086-88, 1440-43, 1611-23.

Protheroe J. (2004): Modern management of menorrhagia. Journal of Family Planning and Reproductive Health care.30 (2): 118-22.

Sandeep Kaur, Reena Jairus, Glory Samuel (2013): Nursing and Midwifery Research Journal, Vol-9, No.3, July.

Shaw JA. and Shaw TM. (2004): Menorrhagia. Updated on June 2004. Available from:www.emedicine.com/med/topic1449.htm. Accessed January 22, 2004

Singh A., Kiran D., Singh H., Nel B., Singh P. and Tiwari P. (2008): Prevalence and severity of dysmenorrhea: a problem related to menstruation, among first and second year female medical students. Indian J Physiol Pharmacol. Oct-Dec; 52(4):389-97.

Stones R., William, Matthews Zö̈ (2012): Gynecological disease in developing countries: Whose burden? Opportunities and Choices Working Paper. 'Opportunities and Choices' 
Reproductive Health Research Southampton Social Statistics Research Institute University of Southampton.Page4.http://www.socstats.soton.ac.uk/choices/Burden\%20of\%20gynae\%20disease \%20working\%20paper\%20WP15.pdf Last cited on 25 October.

Supriya Panda1, P.N Agamanasa1, Sandhya Sri Panda2, TV. Ramani (2013): 1Int J Cur Res Rev: Incidence of Candidiasis and Trichomoniasisin Leucorrhea Patients Feb/ Vol 05 (03).

World Health Organization (2005): Women's health. Geneva: WHO.

WarrilowG., Kirkham C. and Ismail KMK. (2004): "Quantification of menstrual blood loss," The Obstetrician and Gynecologist, vol. 6, pp. 88-92. 


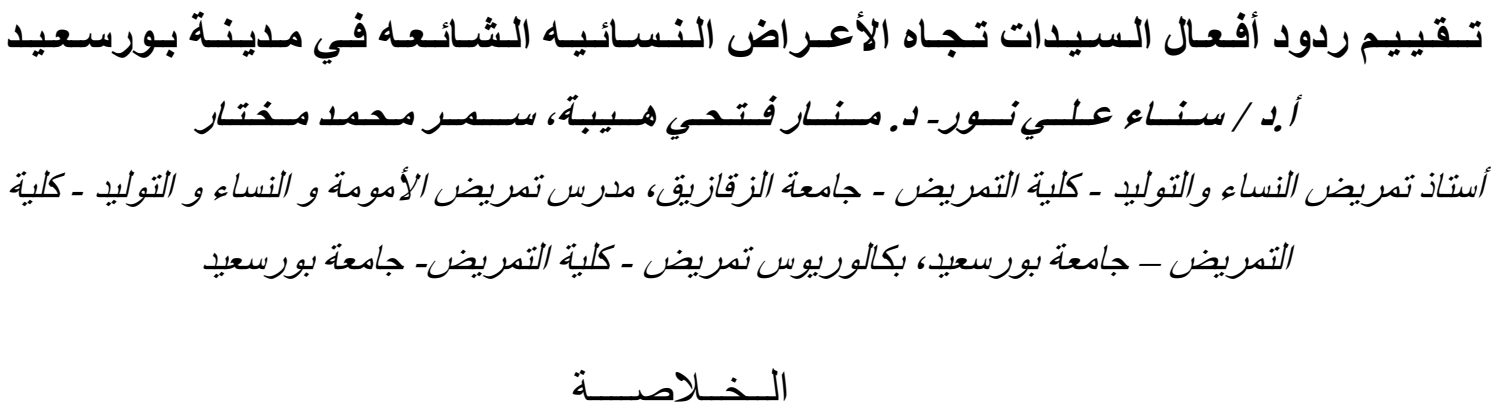

أعر اض النسا هى المؤشر ات الأكثر أهميه لأمر اض النسا ،التى يمكن أن تؤثر بشده على صحة النساء ،الرفاهيه الأجتماعيه و جودة الحياهو الخصوبه والأنتاجيه. هدف هذه الدراسة هو تقييم ردود أفعال السيدات تجاه الأعر اض النسائيه الثائعه فى مدينة بورسعيد. أجريت هذه الدراسة في عيادات أمر اض النساء في خمسه مر اكز صحية في بورسعيد علي 500 سيده، وقد جمعت تلك المعلومات عن طريق استمارة استبيان المقابلة الثخصية، وقد أظهرت نتائج الدراسة أن هنالك حوالي 75.4 ٪ من النساء تعانين من كثرة الأفراز ات المهبليه ، 63.8 ٪ تعانين من ألام فترة الطمث، 58.6 ٪ تعانين من الحكه الفرجيه ، 39.8 ٪ تعانين من غزارة الطمث. تم العثور على علاقة ذات دلالة إحصائية بين البحث عن العلاج و المتغيرات ذات علاقه بين البحث عن المشوره الطبيه و العوامل الاجتماعيه وقد تخلصت الدراسه أنع عدد كبير من النساء تعانين من الأعر اض النسائه الثائعه وأن ردود أفعال بعض النساءقد تكون ضاره ـ ولذلك أوصيت الدر اسة بتطوير ونشر الدور ات التدريبية وبر امج التو عية و التثقيف لكل من صناع القرار و العاملين بالصحة و عيادات النسا للتو عية بمدي خطوره هذه الأعر اض التى تو اجه المر أه و كيفيه التعامل معها.

$$
\text { الـكـلمــات الإســـــرشـــاديــــة : أعراض أمراض النساء ، ردود أفعال السبيدات . }
$$

